\title{
Perancangan e-Marketplace Maswira (Masyarakat Pesisir berwirausaha) pada Dinas Pertanian dan Perikanan Kabupaten Bombana
}

\author{
Nurfitria Ningsi ${ }^{1}$, Sunyanti ${ }^{2}$, Sarimuddin $^{3}$ \\ ${ }^{1}$ Prodi Sistem Informasi, USN Kolaka, Kolaka, Indonesia \\ ${ }^{2,3}$ Prodi Ilmu Komputer, USN Kolaka, Kolaka, Indonesia \\ email: ${ }^{1}$ nurfitrianingsi35@gmail.com, ${ }^{2}$ sunyantimeini@gmail.com, ${ }^{3}$ sarimuddin85@gmail.com
}

\begin{abstract}
Abstrak
Objektif dari studi ini adalah untuk menghasilkan sebuah aplikasi e-Marketplace MASWIRA untuk membantu pihak Dinas Pertanian dan Perikanan Kabupaten Bombana dalam upaya memaksimalkan kesadaran masyarakat akan potensi perikanan didaerah pesisir Kabupaten Bombana Sulawesi Tenggara selain sebagai media promosi produk UMKM bidang Perikanan juga sebagai sarana komunikasi antara Pemda Kab. Bombana dengan masyarakat setempat. Mengingat selama pandemic Covid-19 perekonomian daerah Kab. Bombana ikut mengalami impas negatif khususnya menurunnya omset penjualan. Berkembangnya penggunaan layanan e-commerce yang awalnya hanyalah alternatif saja tapi kini menjadi pintu utama penghubung antara masyarakat dengan UMKM lokal, Perancangan menggunakan model waterfall yang bertujuan menjabarkan Proses pengembangan secara terstruktur sehingga efektif meminimalisir kesalahan dan biaya pengembangan ulang
\end{abstract}

Kata Kunci: e-Marketplace, Masyarakat Pesisir, UML, Waterfall.

\begin{abstract}
The objective of this study is to produce an e-Marketplace application MASWIRA to assist the Department of Agriculture and Fisheries of Bombana Disctrict in an effort to maximize public awareness of the potential of fisheries in the coastal areas of the District Bombana Southeast Sulawesi, apart from being a medium for promoting MSME products in the field of Fisheries, is also a means of communication between the District Government. Bombana with the local community. considering that during the Covid-19 pandemic the regional economy of Bombana District also experienced a negative break-even, especially the decline in sales turnover. The development of the use of e-commerce services which was initially only an alternative but has now become the main link between the community and local MSMEs. The design uses the waterfall model which aims to describe the development process in a structured manner so that it effectively minimizes errors and costs.
\end{abstract}

Keywords: e-Marketplace, Coastal Communities, UML, Waterfall 


\section{PENDAHULUAN}

Indonesia merupakan negara kelautan dengan produksi perikanan tertinggi ketiga di dunia, meskipun terjadi penurunan signifikan selama pandemic covid 19 kini produksinya mulai meningkat dan telah menyumbangkan 3 persen terhadap PDB nasional. Dinas Pertanian dan Perikanan Kabupaten Bombana merupakan lembaga pemerintah yang bergerak dibidang penanganan dibidang pertanian, perkebunan dan perikanan, evaluasi bidang pangan dan perikanan serta pelaksanaan administrasi bidang pangan dan perikanan dimana selama pandemic covid 19 pemerintah Kabupaten Bombana Turut berusaha dalam memutus rantai penyebaran virus covid 19 disisi lain pihak Dinas Pertanian Dan Perikanan Kabupaten Bombana harus memastikan bahwa masyarakat Kabupaten Bombana tidak mengalami penurunan daya beli selama kegiatan pembatasan sosial berlangsung, tidak dapat dipungkiri hal ini mempengaruhi aktivitas ekonomi maupun kebiasaan masyarakat yang sebelum pandemic mereka terbiasa dalam mendistribusikan produk pertanian dan perikanan secara langsung. Jika melirik data ditahun sebelumnya dimana kemampuan hasi tangkap ikan Indonesia menempati posisi kedua di dunia (ekonomi okezone, 2019)

Selama pandemi terjadi perkiraan panen produk perikanan berkisar 450.000 ton dari april sampai juli, disisi perikanan darat seperti ikan air tawar, sebanyak 341 ribu ton; budidaya ikan laut 4.400 ton; dan udang 104.941 ton. Pentingnya sinergi dukungan ekonomi untuk memastikan usaha perikanan terus beraktivitas untuk memenuhi kebutuhan konsumsi secara terus menerus. kedepannya target produksi berbasis perikanan, dapat ikut meroket (Perikanan, 2020). Target produksi perikanan sebelumnya sebesar 18,44 juta ton dan ditahun 2021 meningkat sekitar 19,47 juta ton. Dengan 7,92 juta ton bersumber dari ikan dan 11,55 juta ton bersumber dari rumput laut (Putra, 2020).

Penggunaan e-Marketplace yang semakin dilirik sepanjang pandemi covid 19 selain membawa manfaat kemudahan juga tidak ayalnya hadir bersama kendala di dalamnya berbagai permasalahan yang seringkali terjadi seperti perubahan waktu janji maupun kesulitan menemui pelanggan saat menggunakan jasa penjualan online. Salah satu pertimbangan oleh sebagian kalangan menggunakan $e$ Marketplace khususnya masyarakat level menengah maupun bawah mempunyai kebutuhan yang harus dipenuhi. Penggunaan E-Marketplace khususnya pada layanan catering makanan memungkinkan barang yang awalnya belum di kenal masyarakat luas ketika menggunakan iklan dengan media umum atau melalui sarana brosur dan info dari orang keorang (Andrean et al., 2017).

Beberapa pertimbangan berikut menjadi hal penting yakni e-Marketplace dapat membantu penyewa dan user dalam meningkatkan nilai jual produk leasing (Hendry, 2018). Kemudahan dalam memasarkan produk dan proses transaksi yang aman dan nyaman dari sisi buyer dan seller (Imam \& Nugraha, 2018). Kemudahan promosi dan penjualan produk dengan memberikan rekomendasi jasa catering sesuai harapan serta terdekat dari jarak pelanggan (Andrean et al., 2017). Merujuk dari beberapa pertimbangan di atas Pentingnya membangun e-Marketplace Maswira diharapkan akan membantu pihak dinas Pertanian dan perikanan Kabupaten Bombana dalam mempromosikan produk komoditas unggul masyarakat pesisir Kabupaten Bombana sehingga mampu mengakses investor untuk pemasaran produk.

\section{METODE PENELITIAN}

Penggunaan Metode waterfall sebagai metode perancangan e-markeplace ini mengingat beberapa kelebihan yang ditawarkan oleh metode ini antara lain hemat biaya karena proses pembangunan dilakukan secara berurutan selain itu alur kerja juga sangat jelas sehingga proses koordinasi tim relatif cepat. Beberapa alasan lain yaitu pertimbangan historis Metode waterfall yang digunakan dapat dilihat pada Gambar 1. Metode pengembangan perangkat lunak ini adalah metode ini dikembangkan oleh Winston Royce yang menerapkan sistem linear dan output linear dari masukan dan tahapannya mengikuti adaptasi pengembangan perangkat keras, dimana saat itu belum metode lain selain metode 
ini. Proses pembangunan terstruktur yang digunakan dapat meminimalisir potensi kerugian karena kesalahan perancangan yang mengakibatkan pembengkakan biaya pengerjaan ulang(Rosa AS, 2014).

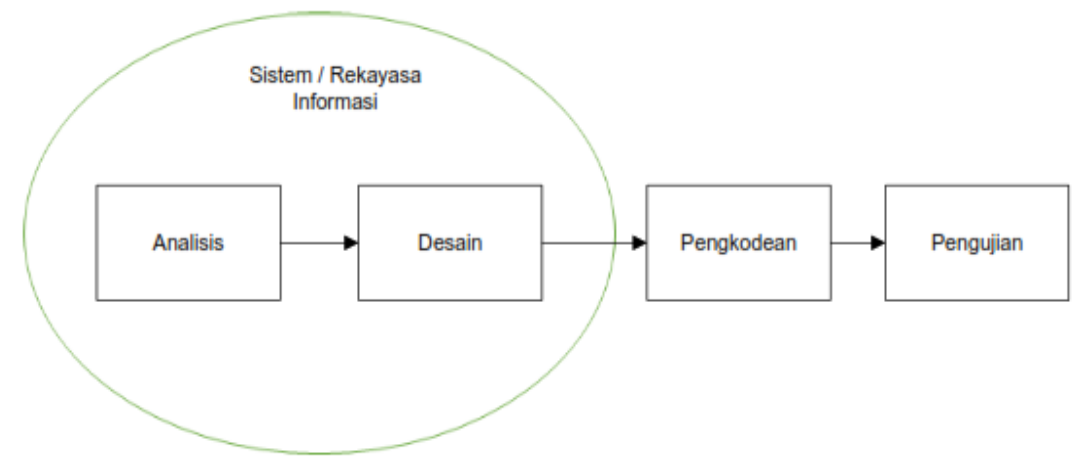

Gambar 1. Metode Waterfall

Penelitian dilakukan di Dinas Pertanian Kabupaten Bombana Sulawesi Tenggara dengan alur penelitian dijabarkan dalam Gambar 2 berikut ini:

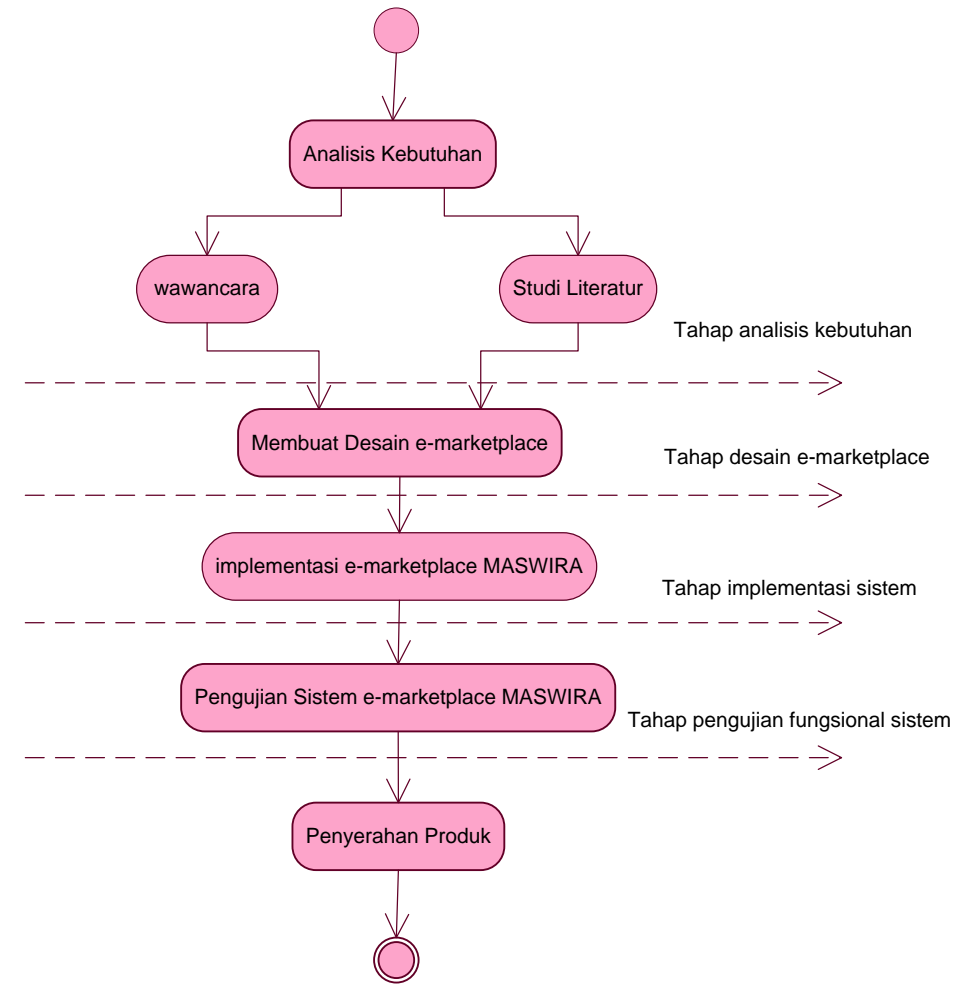

Gambar 2. Alur penelitian

Tahapan perancangan aplikasi e-marketplace M A S W I R A terdiri atas beberapa aktivitas berikut ini :

a. Analisis Kebutuhan

Menganalisis permasalahan dari hasil wawancara terstruktur kepada pihak Dinas Pertanian dan Perikanan Kabupaten Bombana sehingga diperoleh gambaran solusi IT yang dibutuhkan untuk mengatasi masalah tersebut

b. Desain e-marketplace

Merancang desain sistem yang dibutuhkan menggunakan UML sebagai tools utama pemodelan perangkat lunaknya

c. Pengkodean sistem

Implementasi sistem kedalam kode program. penggunaan tools XAMPP dan Browser google crome 
d. Pengujian fungsional sistem

Melakukan pengujian fungsionalitas sistem untuk memastikan semua fungsi sistem berjalan sesuai dengan seharusnya

e. Penyerahan produk kepada pengguna Akhir

Penyerahan produk ditandai dengan Pihak dinas Menggunakan Layanan e-marketplace MASWIRA

\section{HASIL DAN PEMBAHASAN}

Perancangan sistem e-Marketplace ini difokuskan pada perancangan etalase produk yang memungkinkan pengunjung untuk melihat-lihat produk e-Marketplace sejalan dengan tuntutan pelanggan terus mengalir di sisi lainnya tuntutan promosi penawaran produk kepada pelanggan terus digulirkan (Imam \& Nugraha, 2018). Pada Sistem e-Marketplace ini proses pengelolaan transaksi penjualan produk kepada pelanggan dilakukan diluar sistem dalam hal ini ketika pengunjung tertarik untuk membeli produk dari etalase produk mereka dapat menghubungi seller melalui nomor telefon pribadi yang tertera pada submenu detail produk e-Marketplace MASWIRA. Adapun tahapan desain sistem $e$-Marketplace MASWIRA adalah sebagai berikut;

\section{Desain e-marketplace}

a. Usecase diagram

Diagram ini berfungsi untuk menggambarkan fungsionalitas sistem $e$-Marketplace MASWIRA yang dapat dilihat pada Gambar 3.

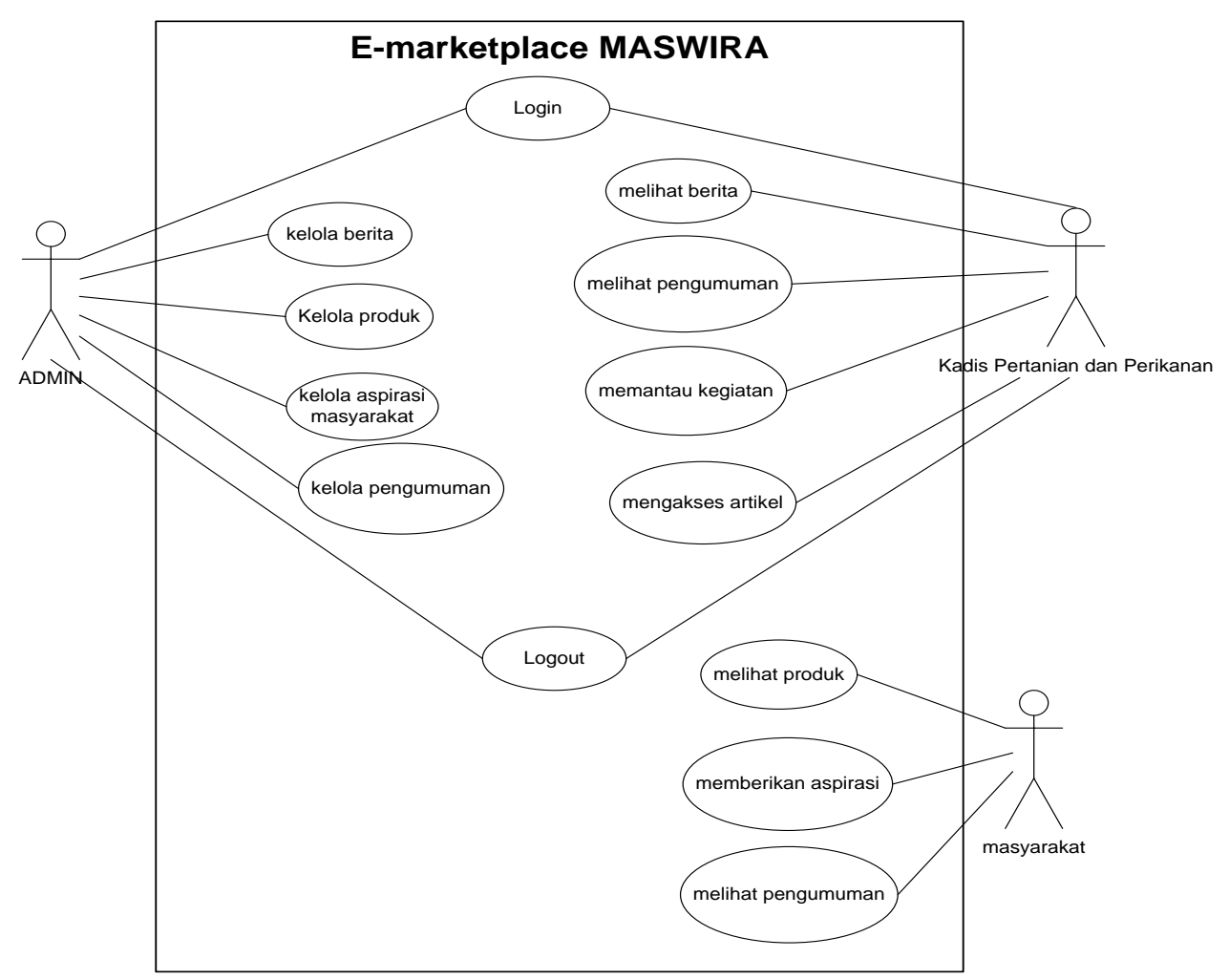

Gambar 3. Usecase Diagram E-Marketplace MASWIRA

b. Activity diagram input kategori produk

Diagram ini menggambarkan alur pengelolaan kategori produk dalam e-Marketplace MASWIRA yang dapat dilihat pada Gambar 4. 


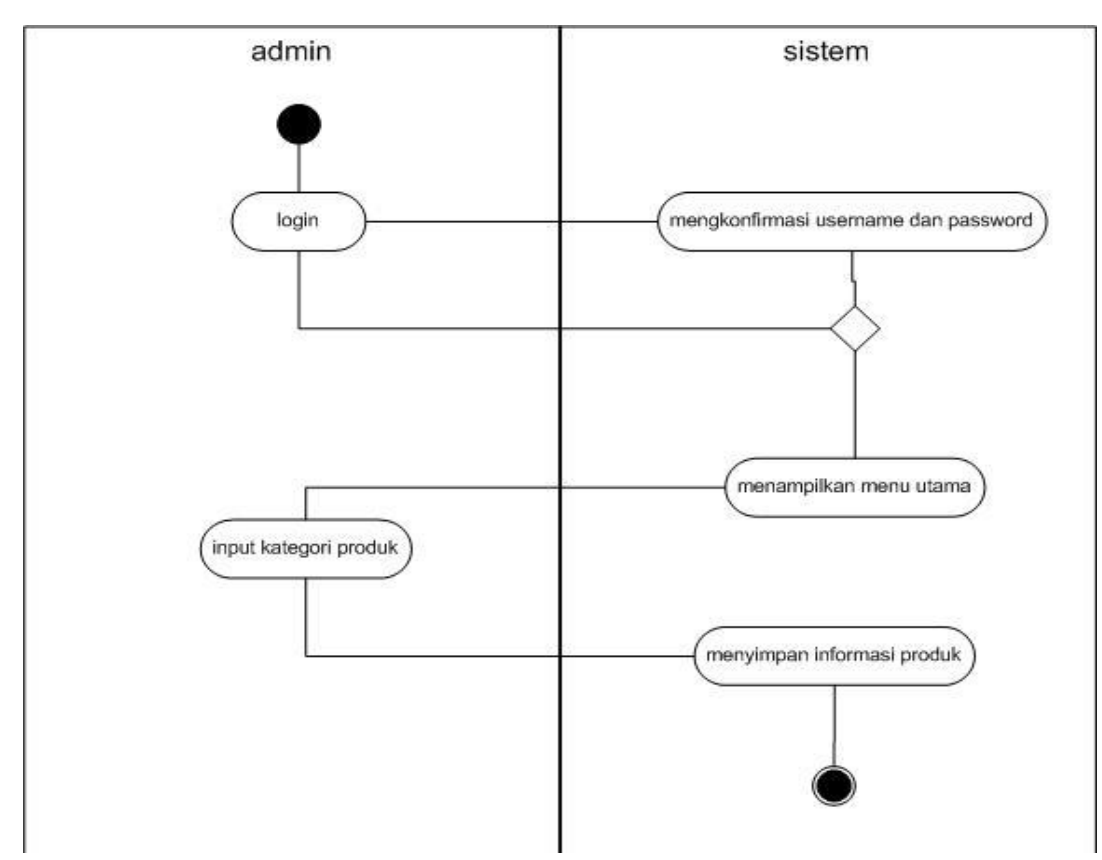

Gambar 4. Activity diagram input kategori produk

c. Activity diagram membaca artikel

Activity diagram membaca artikel pada Gambar 5 ini berfungsi untuk menampilkan informasi berita,artikel maupun pengumuman yang ada di situs MASWIRA yaitu http://saktigembira.bombanakab.go.id/MASWIRA

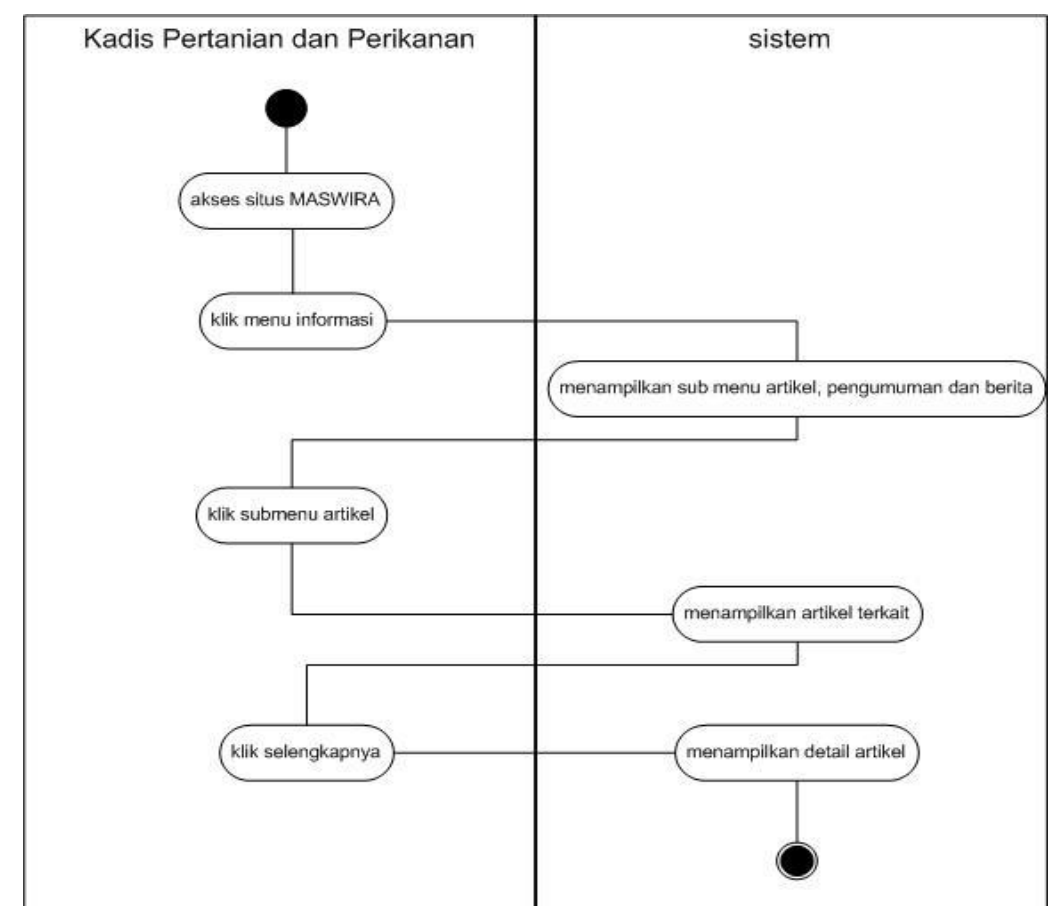

Gambar 5. Activity diagram membaca artikel

d. Desain tampilan login admin

Gambar 6 menunjukkan desain tampilan login admin pada situs MASWIRA. 


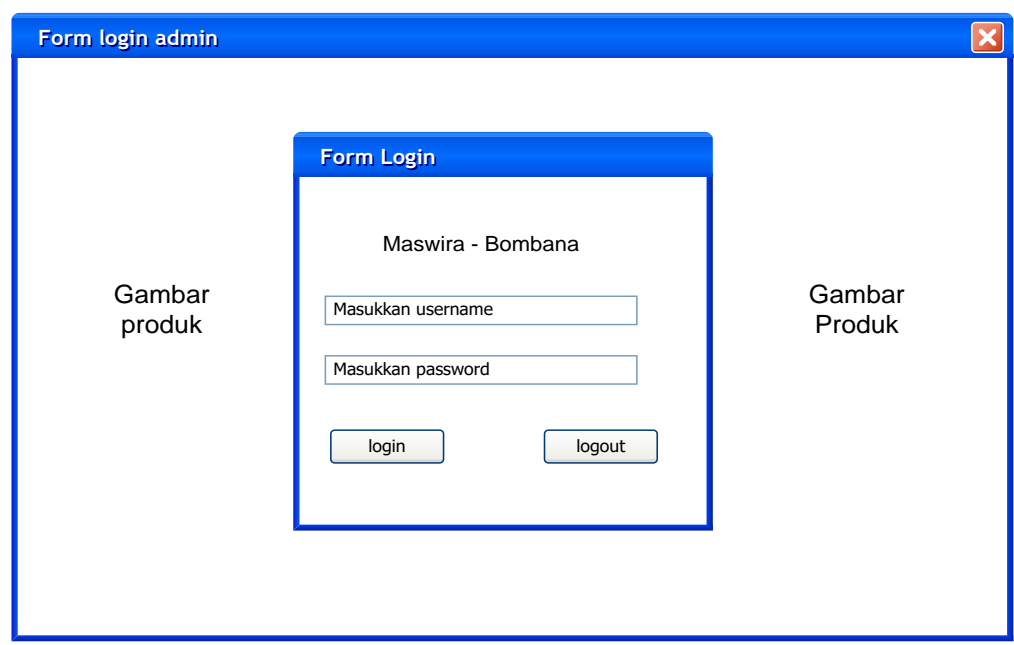

Gambar 6. Desain tampilan login admin

e. Desain awal Tampilan form market

Gambar 7 merupakan desain awal tampilan form market pada situr MASWIRA.

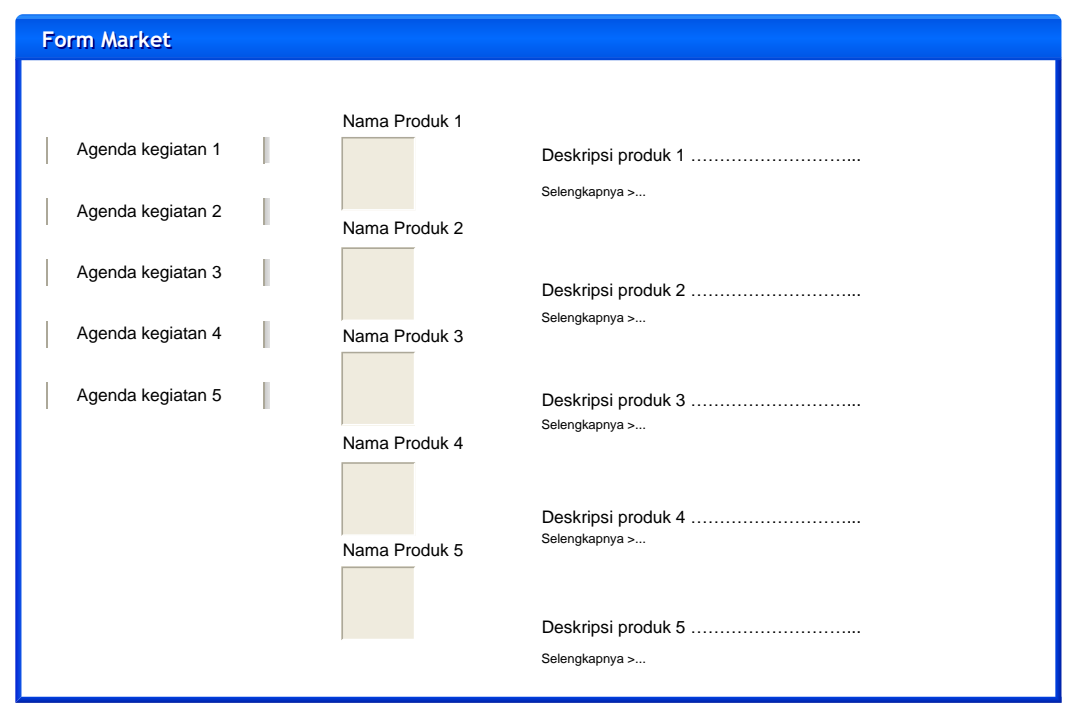

Gambar 7. Desain awal Tampilan form market

f. Desain tampilan submenu tampil market

Gambar 8 memperlihatkan desain tampilan submenu tampil market.

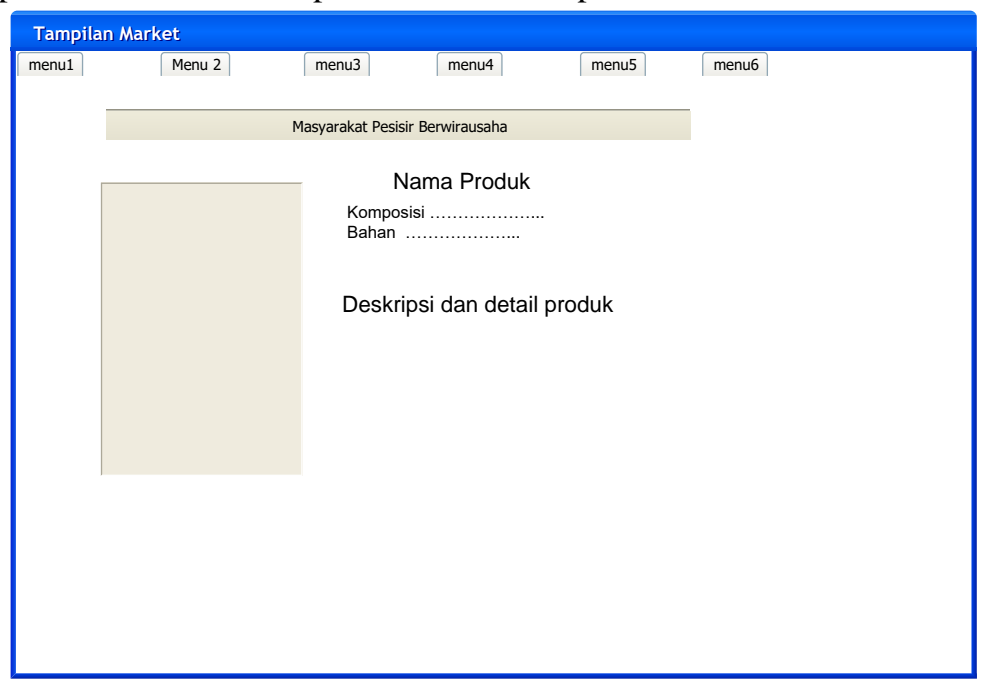

Gambar 8. Desain tampilan submenu tampil market

56 | Perancangan e-Marketplace Maswira (Masyarakat Pesisir berwirausaha) pada Dinas Pertanian dan Perik ... 


\section{Pengkodean Sistem}

Berikut beberapa tampilan e-Marketplace pada Menu login admin yang dapat dilihat pada Gambar 9 .

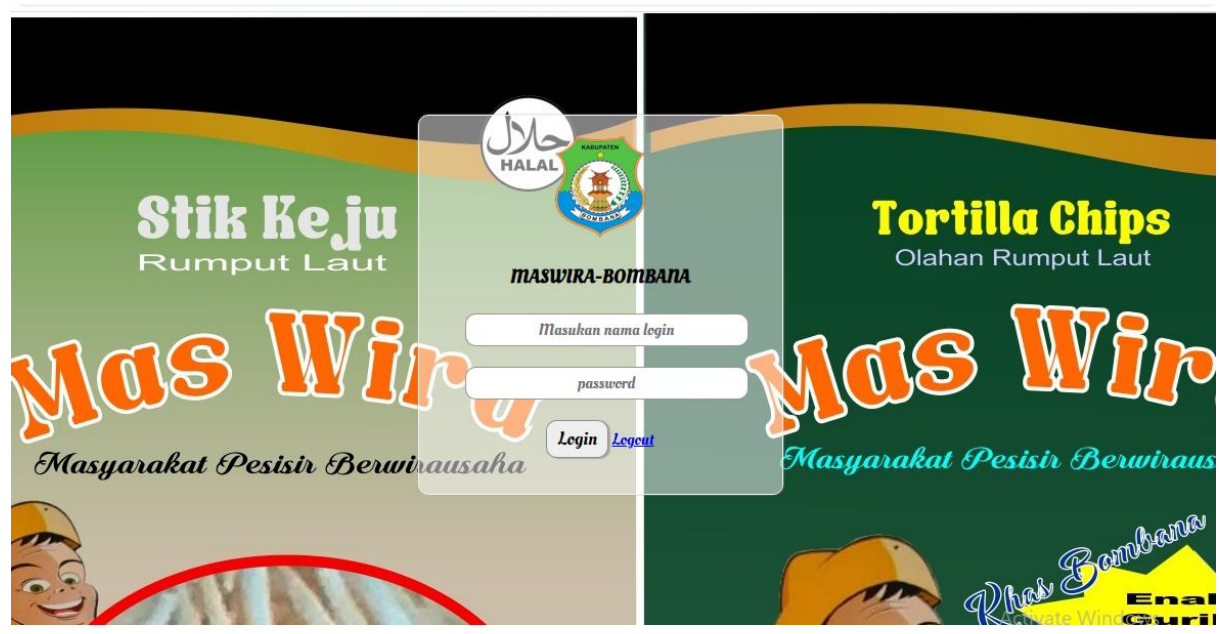

Gambar 9. Menu login admin

Tampilan submenu tampil market pada gambar 10 berfungsi untuk menampilkan detail produk UMKM Masyarakat pesisir Kabupaten Bombana.

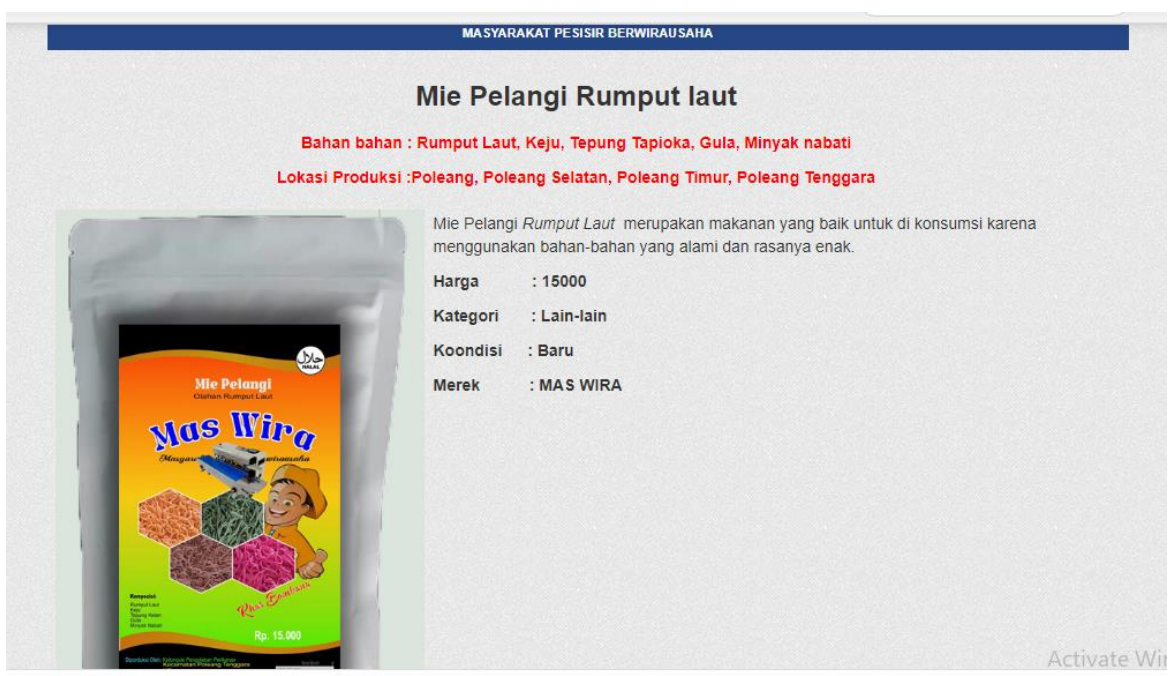

Gambar 10. Submenu tampil market

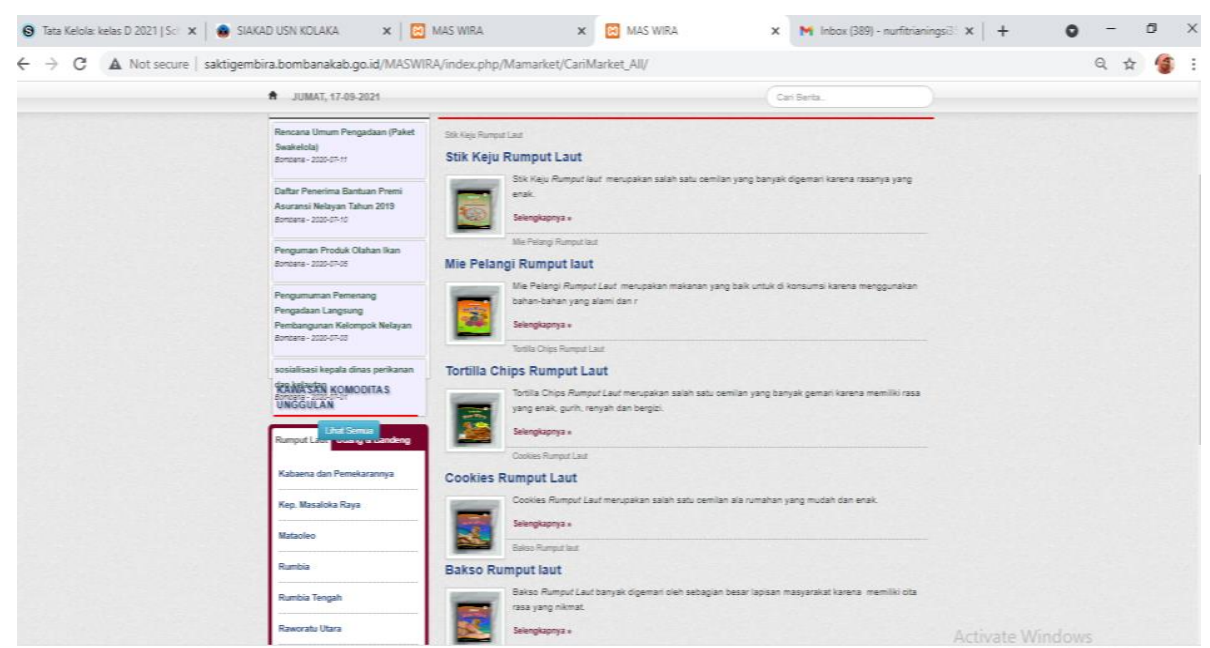

Gambar 11. Menu list produk 
Tampilan menu list produk ditunjukkan pada Gambar 11. Menu ini berfungsi untuk menampilkan produk-produk yang telah disimpan oleh admin dalam sistem, produk tersebut ditampilkan dalam etalase sistem $e$-Marketplace MASWIRA dengan berbagai jenis produk Perikanan dan Pertanian Masyarakat Pesisir Kabupaten Bombana.

\section{KESIMPULAN}

Perancangan e-Marketplace MASWIRA ini mengusulkan setidaknya dua kesimpulan utama yakni Aplikasi ini memudahkan masyarakat dalam mengetahui produk unggul masyarakat pesisir kabupaten bombana sehingga memungkinkan bagi investor untuk merambah pangsa pasar lokal Kabupaten Bombana. Penelitian selanjutnya mempertimbangkan pentingnya empati kepada pengguna serta adanya jaminan atas layanan yang diberikan akan berpengaruh terhadap intensitas penggunaan layanan e-government dimasa mendatang (Ningsi et al., 2021) baik melalui pembenahan infrastruktur pendukung layanan maupun aspek afektif lainnya (Ningsi et al., 2020)

\section{UCAPAN TERIMA KASIH}

Penulis mengucapkan terima kasih kepada LPPM USN Kolaka yang telah memberi dukungan materi dan finansial terhadap penelitian ini.

\section{DAFTAR PUSTAKA}

Andrean, M., Saputra, E., \& Sugiarso, T. (2017). Perancangan Dan Implementasi Sistem Informasi E-Marketplace Untuk Katering. Jurnal Teknologi Informasi, 5(2), 1-10.

Ekonomi okezone. (2019). 5 Negara dengan Hasil Ikan Terbesar Dunia, Indonesia Urutan Berapa? Ekonomi Okezone. https://economy.okezone.com/

Hendry, T. M. Z. (2018). Aplikasi E-Commerce Sebagai Jembatan Perancang dan Konsumen Pada T-Shirt Design. JuTISI ( Jurnal Teknik Informatika Dan Sistem Informasi ), 4(65), 405 - 416.

Imam, R., \& Nugraha, A. R. (2018). Perancangan Sistem Informasi E-Marketplace Original Clothing Indonesia Berbasis Web. Jurnal Manajemen Dan Teknik Informatika, 1(1), 51-60. http://jurnal.stmikdci.ac.id/index.php/jumantaka/article/view/266

Ningsi, N. G. N. . (2021). ANALISIS KUALITAS LAYANAN E- GOVERMENT MENGGUNAKAN METODE SERVQUAL (STUDI KASUS KANTOR SAMSAT KOLAKA). 4(28), 10-18.

Ningsi, N., Z, N., \& Gusnawati, G. (2020). Quality Analysis of E-government Services Using SERVQUAL Method (Case Study of SAMSAT Office in Kolaka Regency). INTENSIF: Jurnal Ilmiah Penelitian Dan Penerapan Teknologi Sistem Informasi, 4(2), 142-158. https://doi.org/10.29407/intensif.v4i2.13707

Perikanan, K. K. dan P. (2020). Pandemi Covid-19, Estimasi Panen Perikanan Budidaya Capai 450 Ribu Ton Sepanjang April Hingga Juni 2020. Biro Humas Dan Kerja Sama Luar Negeri. https://kkp.go.id/artikel/18532-pandemi-covid-19-estimasi-panen-perikanan-budidaya-capai-450-ribu-tonsepanjang-april-hingga-juni-2020

Putra, D. A. (2020). KKP Target Produksi Perikanan Budidaya Capai 19,47 Juta Ton di 2021. Merdeka.Com. https://www.merdeka.com/uang/kkp-target-produksi-perikanan-budidaya-capai-1947-juta-ton-di2021.html\#: :text=Merdeka.com - Kementerian Kelautan dan,sebanyak 18\%2C44 juta ton.

Rosa AS, m. S. (2014). Rekayasa Perangkat Lunak: Terstruktur dan berorientasi objek. Informatika. 